\title{
Vitamin-D levels in exclusively breast fed infants less than six months of age: Do they need supplementation?
}

\author{
Tushar Jagzape $^{1}$, Saherish Khan ${ }^{2}$ \\ Sri Lanka Journal of Child Health, 2014; 43(2): 92-96
}

\begin{abstract}
Introduction: There is growing interest in subclinical vitamin $\mathrm{D}$ deficiency for the non-skeletal health benefits. There is good evidence that breastfed babies not supplemented with vitamin D have low vitamin D concentration and are at risk of rickets.

Hypothesis: Exclusively breastfed babies often have low levels of vitamin D and are at risk of having rickets if not supplemented with vitamin D.
\end{abstract}

Objective: Measurement of serum 25(OH) D levels in exclusively breastfed babies.

Method: It was an observational, cross sectional study. Thirty healthy infants less than 6 months of age, on exclusive breast feeding and not on any vitamin supplementation were randomly selected. Vitamin D, serum calcium, phosphorus and alkaline phosphatase levels were measured in all these babies and those with clinical features of rickets were subjected for $\mathrm{x}$-ray evaluation.

Results: Twenty eight (93.3\%) had hypovitaminosis $\mathrm{D}$ (value $<20 \mathrm{ng} / \mathrm{ml}$ ) including severe deficiency $(<5 \mathrm{ng} / \mathrm{ml})$ in two babies $(6.7 \%)$. The mean value of vitamin D level was $8.871 \pm 4.78 \mathrm{ng} / \mathrm{ml}$. The mean ionic calcium value was $5.07 \pm 0.67$ and the mean inorganic phosphorus value was $6.25 \pm 1.18 \mathrm{mg} / \mathrm{dl}$, which were normal for this age group. The alkaline phosphatase level was uniformly elevated with 28 $(93.3 \%)$ babies having values $>420 \mathrm{U} / \mathrm{L}$. There was no statistically significant relationship between vitamin D levels and the birth weight or nutritional status of the infant. Radiological changes were found in three $(10 \%)$ babies.

Conclusion: Vitamin D deficiency is highly prevalent in exclusively breastfed healthy infants and hence vitamin D should be supplemented.

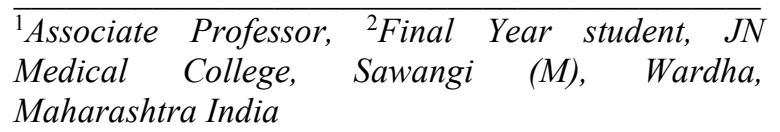

(Received on 23 August 2013: Accepted after revision on 27 September 2013)

(Key words: Exclusively breastfed infants; vitamin D deficiency; subclinical rickets)

\section{Introduction}

Vitamin D, the generic term for a family of secosteroids with anti-rachitic activity, comprises a family of fat soluble vitamins and hormones that, when deficient in the diet, causes rickets from defective mineralization of growing bone and osteomalacia in non- growing bones ${ }^{1}$. Vitamin $\mathrm{D}_{2}$ (ergocalciferol), obtained from the influence of ultraviolet $\mathrm{B}$ radiations on plants and yeast and vitamin $\mathrm{D}_{3}$ (cholecalciferol), produced in skin by ultraviolet rays are the two main forms of vitamin D. Both forms are metabolized similarly in the body, first by hepatic 25 hydroxylation into inactive but stable $25(\mathrm{OH}) \mathrm{D}$ (Calcidiol) and then by renal 1hydroxylation into active but unstable $1,25(\mathrm{OH})_{2} \mathrm{D}$ (Calcitriol). Calcitriol exerts its effects by binding to vitamin D receptor, which belongs to the family of nuclear hormone receptors ${ }^{2}$.

Vitamin-D deficiency is associated with a higher risk of autoimmune diseases and several forms of malignancy, such as prostate, colon and breast cancer $^{3}$. Rickets is an extreme form of vitamin D deficiency and represents the tip of vitamin D deficiency iceberg ${ }^{4}$. Serum $25(\mathrm{OH})$ vitamin D level is the best available biomarker for the diagnosis of vitamin D deficiency ${ }^{5}$. Many breastfed infants, not supplemented with vitamin D during the first 6 months of life have serum vitamin D concentrations $<50 \mathrm{nmol} / \mathrm{L}$ and are therefore at increased risk of rickets. This is especially true for infants who have high skin pigmentation and little sun exposure ${ }^{6}$. Most of the available data are from western countries and urban Indian populations; hence we undertook this study to measure vitamin $\mathrm{D}$ level in exclusively breast fed babies in a rural population around Wardha city in Central India.

\section{Hypothesis}

Exclusively breastfed babies often have low levels of vitamin-D and are at risk of having rickets if not supplemented with vitamin-D. 


\section{Objectives}

- The primary objective was the measurement of serum $25(\mathrm{OH})$ D levels in exclusively breastfed babies below six months of age.

- Secondary objectives were:

- Measurement of serum calcium (ionic), phosphorus and alkaline phosphatase in these babies.

- Clinical correlation with biochemical parameters viz. calcium, phosphorus and alkaline phosphatase for vitamin D deficiency.

- Correlation of vitamin-D levels with gestational age and birth weight.

\section{Method}

Study design: Observational, cross-sectional study.

Setting: Well baby clinic of tertiary care rural Teaching Hospital of Central India.

Subjects: Following statutory clearance from the Institutional Ethical Committee and after obtaining informed consent from parents, 30 healthy, breast fed infants, fulfilling the study inclusion criteria; were randomly selected.

Inclusion criteria: Exclusively breast fed infants below six months of age, not receiving any vitamin supplements containing vitamin D or vitamin-D fortified formulas.

Exclusion criteria: Age less than 28 days (neonates), critically sick infants, formula fed babies and babies receiving vitamin-D supplements.

These infants were subjected to a thorough examination for clinical evidence of vitamin-D deficiency. Their demographic profile, birth weight, dietary history and clinical examination, including anthropometry findings, were recorded in the structured proforma.

The birth weight was recorded from the medical records whenever available or as told by the mother. Birth weight $<2500 \mathrm{~g}$ irrespective of gestational age was considered as low birth weight ${ }^{7}$. Baby born with a gestation of $<37$ completed weeks was considered preterm ${ }^{8}$. Exclusive breast feeding was defined as no food or liquid other than breast milk, not even water, given to infant from birth by mother, health care provider, or family member/supporter ${ }^{9}$. Clinical examination was done by author using standard methods. Weight was recorded with minimal clothes on an electronic weighing machine with a minimum reading of $5 \mathrm{~g}$. Length was measured using an infantometer with minimum reading of $0.1 \mathrm{~cm}$ with accuracy $\pm 0.5 \mathrm{~cm}$. Head circumference and chest circumference were recorded with help of fiber tape using standard methods. Nutritional status was assessed using WHO growth charts ${ }^{10}$.

Blood samples of these infants were collected for estimation of serum $25(\mathrm{OH}) \mathrm{D}$, calcium, phosphorus and alkaline phosphatase levels. Biochemical tests for serum $25(\mathrm{OH}) \mathrm{D}$ levels were conducted by $\mathrm{M} / \mathrm{s}$ Religare Laboratories using fully automated chemi luminescent immunoassay method. The serum ionic calcium was measured using calcium arsenazo method, serum phosphorus by colorimetry method and alkaline phosphatase by p-nitro phenyl phosphate kinetic method at the central laboratory of the hospital. The normal values of these parameters in relation to age of the baby were obtained from the Harriet Lane handbook $18^{\text {th }}$ edition ${ }^{11}$. Babies with overt clinical findings were subjected to radiological examinations. X -rays of both wrists, antero-posterior and lateral views, were taken. These were reported by a senior radiologist who was unaware of the vitamin D status of these babies. The vitamin D status was categorized as follows: ${ }^{2}$

- Severe deficiency $<5 \mathrm{ng} / \mathrm{ml}$

- Deficiency $<15 \mathrm{ng} / \mathrm{ml}$

- Insuffficiency $15-20 \mathrm{ng} / \mathrm{ml}$

- Sufficiency $20-100 \mathrm{ng} / \mathrm{ml}$

- Excess $>100 \mathrm{ng} / \mathrm{ml}$

- Intoxication $>150 \mathrm{ng} / \mathrm{ml}$

The data was arranged in Microsoft excel sheets. The average values, standard deviation and other statistical analyses (Fisher's exact test, unpaired $\mathrm{t}$ test) were done using Microsoft excel and GraphPad InStat software demo version.

\section{Results}

Of the 30 babies fulfilling the inclusion criteria 14 (46.7\%) were male and $16(53.3 \%)$ were female giving a male: female ratio of $1: 1.4$. The average age of the babies in the study was 2.7 months, the youngest being 1 month (three babies) and the oldest being 6 months (two babies). All the babies were born at term. Preterm babies were not recruited as all of them were on vitamin supplementation. All 30 babies were on exclusive breast feeding. The vitamin D status of the babies is shown in Table 1 . 
Table 1: Vitamin D status of babies

\begin{tabular}{|l|c|}
\hline Vitamin D status (ng/ml) & No. of babies (\%) \\
\hline Severe deficiency $(\leq 5)$ & $02(06.7 \%)$ \\
\hline Deficient $(\leq 15)$ & $25(83.3 \%)$ \\
\hline Insufficient $(15-20)$ & $01(03.3 \%)$ \\
\hline Sufficient $(20-100)$ & $02(06.7 \%)$ \\
\hline
\end{tabular}

Out of the 30 babies, $28 \quad(93.3 \%)$ had hypovitaminosis $\mathrm{D}$ (value below $20 \mathrm{ng} / \mathrm{ml}$ ). The mean vitamin D level was $8.871 \pm 4.78 \mathrm{ng} / \mathrm{ml}$. There were no babies with vitamin $\mathrm{D}$ excess (values above $100 \mathrm{ng} / \mathrm{ml}$ ) or intoxication (values above $150 \mathrm{ng} / \mathrm{ml}$ ).

The biochemical parameters are shown in Table 2 .

Table 2: Biochemical parameters of the 30 babies

\begin{tabular}{|l|c|c|c|c|c|}
\hline \multicolumn{1}{|c|}{ Parameter } & $\begin{array}{c}\text { Normal } \\
\text { range }\end{array}$ & $\begin{array}{c}\text { Mean } \pm \\
\text { SD }\end{array}$ & $\begin{array}{c}\text { Low values } \\
\text { Number (\%) }\end{array}$ & $\begin{array}{c}\text { High values } \\
\text { Number (\%) }\end{array}$ & $\begin{array}{c}\text { Normal values } \\
\text { Number (\%) }\end{array}$ \\
\hline Serum calcium ionic (mg/dl) & $4.2-5.48$ & $5.07 \pm 0.67$ & $01(03.3)$ & $05(16.7)$ & $24(80.0)$ \\
\hline Serum inorganic phosphorus (mg/dl) & $4.5-6.7$ & $6.25 \pm 1.18$ & $03(10.0)$ & $07(23.3)$ & $20(66.7)$ \\
\hline Serum alkaline phosphatase (U/L) & $145-420$ & $643 \pm 195$ & nil & $28(93.3)$ & $02(06.7)$ \\
\hline
\end{tabular}

Serum alkaline phosphatase levels were uniformly raised. Serum calcium levels were normal in $80 \%$. Serum phosphorus levels were low in $10 \%$ and normal in $66.7 \%$ babies, suggesting early vitamin D deficiency.

The nutritional status of the babies as per WHO charts is shown in Table 3.

Table 3: Nutritional status as per WHO charts

\begin{tabular}{|l|c|}
\hline \multicolumn{1}{|c|}{ Weight for age } & No. of babies (\%) \\
\hline$<3^{\text {rd }}$ percentile & $06(20.0)$ \\
\hline $3^{\text {rd }}-15^{\text {th }}$ percentile & $05(16.7)$ \\
\hline $15^{\text {th }}-50^{\text {th }}$ percentile & $12(40,0)$ \\
\hline $50^{\text {th }}-85^{\text {th }}$ percentile & $05(16.7)$ \\
\hline $85^{\text {th }}-97^{\text {th }}$ percentile & $02(06.7)$ \\
\hline
\end{tabular}

Twenty percent of babies were below the $3^{\text {rd }}$ percentile. Eighty percent were between the $3^{\text {rd }}$ and $97^{\text {th }}$ percentile.

The vitamin D status in relation to nutritional status is shown in Table 4.

Table 4: Vitamin D status in relation to nutritional status

\begin{tabular}{|l|l|l|}
\hline \multicolumn{1}{|c|}{$\begin{array}{c}\text { Vitamin D status } \\
(\mathbf{n g} / \mathbf{m l})\end{array}$} & $\begin{array}{c}\text { Wt. for } \\
\text { age }<\mathbf{3}^{\text {rd }} \\
\text { percentile } \\
(\mathbf{\%})\end{array}$ & $\begin{array}{c}\text { Wt. for age } \\
\mathbf{> 3}^{\text {rd }} \\
\text { percentile } \\
(\mathbf{\%})\end{array}$ \\
\hline Severe deficiency $(\leq 5)$ & $01(16.7)$ & $01(04.2)$ \\
\hline Deficient $(\leq 15)$ & $05(83.3)$ & $20(83.3)$ \\
\hline Insufficient $(15-20)$ & - & $01(04.2)$ \\
\hline Sufficient $(20-100)$ & - & $02(08.3)$ \\
\hline Total & $06(100)$ & $24(100)$ \\
\hline
\end{tabular}

Out of the 24 well-nourished babies 22 (91.7\%) were deficient in vitamin D. All $6(100 \%)$ malnourished babies were vitamin $\mathrm{D}$ deficient. There was no significant relationship between vitamin $\mathrm{D}$ level and nutritional status (P value, by Fisher`s exact test $=1$ )

Only five (16.7\%) out of the 30 babies had clinical features suggestive of rickets. Of these, 4 babies had wide fontanelles and one had wrist widening. Three of the five had radiological evidence of early rickets. The rest had subclinical (biochemical) hypovitaminosis $\mathrm{D}$.

The vitamin D status in relation to birth weight is shown in Table 5.

Table 5: Vitamin D status and birth weight

\begin{tabular}{|c|c|c|}
\hline $\begin{array}{c}\text { Vitamin D } \\
\text { status }\end{array}$ & $\begin{array}{c}\text { Low birth } \\
\text { weight (\%) } \\
\mathbf{N = 7}\end{array}$ & $\begin{array}{c}\text { Normal birth } \\
\text { weight (\%) } \\
\mathbf{N = 2 3}\end{array}$ \\
\hline$<5$ & $01(14.3)$ & $01(04.3)$ \\
\hline$<15$ & $05(71.4)$ & $20(87.0)$ \\
\hline $15-20$ & 0 & $01(04.3)$ \\
\hline$>20$ & $01(14.3)$ & $01(04.3)$ \\
\hline Average & $9.79 \pm 5.27$ & $8.58 \pm 4.78$ \\
Vitamin D level & & \\
\hline
\end{tabular}

Both low birth weight and normal weight babies had high prevalence of vitamin D deficiency. There was no statistically significant difference in the average vitamin $\mathrm{D}$ levels in both groups. (unpaired-t test, $\mathrm{P}=$ $0.56)$. There was no significant relation between birth weight and vitamin $\mathrm{D}$ level $(\mathrm{P}=0.42$, Fischer`s exact test) 


\section{Discussion}

In our study $93.3 \%$ had hypovitaminosis D (vitamin D level $<20 \mathrm{ng} / \mathrm{ml}$ ) and the mean vitamin D level was $8.871+4.78 \mathrm{ng} / \mathrm{ml}$. In the study by Jain $\mathrm{V}$, et al of vitamin $\mathrm{D}$ deficiency in healthy breast fed term infants at 3 months, the prevalence rate was $86.5 \%{ }^{12}$. Agarwal $\mathrm{N}$, et al in their study found the mean vitamin D level was $11.55 \pm 7.17 \mathrm{ng} / \mathrm{ml}$ at 10 weeks and $16.96 \pm 13.33 \mathrm{ng} / \mathrm{ml}$ at 6 months of age ${ }^{13}$. In their study $55.7 \%$ infants at 10 weeks had moderate vitamin deficiency and at 6 months $44.3 \%$ were moderately deficient, $16.5 \%$ developing rickets ${ }^{13}$. Bhalala U, et al have found an $80 \%$ prevalence of subclinical hypovitaminosis D at 3 months ${ }^{14}$. A study by Seth et al. on vitamin $D$ nutritional status of exclusively breast fed infants and their mothers found a mean vitamin D level of $11.6 \pm 8.3 \mathrm{ng} / \mathrm{ml}$ with $43.2 \%$ of infants having levels below $10 \mathrm{ng} / \mathrm{ml}^{15}$. A Western study found $10 \%$ and $37 \%$ prevalence of vitamin deficiency during summer and winter respectively ${ }^{16}$, and another had $12 \%$ prevalence $^{17}$.

Mean ionic calcium value in our study was $5.07 \pm$ $0.67 \mathrm{mg} \%(10.15 \pm 0.8)$, which is normal for age and is similar to values of Jain V et al $(10 \pm 0.8)$ and Bhalala $\mathrm{U}$ et al $(10.13 \pm 0.78)$. Only one baby $(3.33 \%)$ had hypocalcaemia versus $7.1 \%$ in Jain V et al study ${ }^{12,14}$.

Normal inorganic phosphorus and normal alkaline phosphatase levels range from 10 days to 24 months are $4.5-6.7 \mathrm{mg} / \mathrm{dl}$ and $145-420 \mathrm{U} / \mathrm{L}$ respectively. The average inorganic phosphorus level in our study was $6.25 \pm 1.18 \mathrm{mg} / \mathrm{dl}$ and alkaline phosphatase level was $643 \pm 195 \mathrm{U} / \mathrm{L}$. These values are similar to those in other studies ${ }^{12,14}$.

The average alkaline phosphatase value was uniformly increased, with $28(93.3 \%)$ babies having value $>420 \mathrm{U} / \mathrm{L}$, which may suggest hypovitaminosis D. Bhalala et al in their study had found elevated alkaline phosphatase level in only $51 \%$ of patients with low vitamin $\mathrm{D}^{14}$. Ziegler $\mathrm{EE}$ et al in their study found an occasional elevated alkaline phosphatase value, but no significant differences in alkaline phosphatase activity between vitamin $\mathrm{D}$ deficient and sufficient subjects ${ }^{18}$, suggesting inconsistent relation between $25(\mathrm{OH}) \mathrm{D}$ and alkaline phosphatase levels ${ }^{17}$.

Of the 30 babies $20 \%$ were below the $3^{\text {rd }}$ percentile of weight for age and sex as per WHO charts. The mean vitamin D levels in malnourished babies and wellnourished babies were $8.35 \pm 3.83 \mathrm{ng} / \mathrm{ml}$ and 8.99 $\pm 5.05 \mathrm{ng} / \mathrm{ml}$ respectively. All $(100 \%)$ babies with weight for age $<3^{\text {rd }}$ percentile had vitamin $D$ deficiency, whereas $91.7 \%$ of well-nourished babies too had vitamin $\mathrm{D}$ deficiency. This was statistically insignificant. $(\mathrm{P}=0.608)$

In this study sample only $16.7 \%$ had clinical features of vitamin D deficiency and only $10 \%$ had radiological features of early rickets. Bhalal et al observed in their study at 3 months of age that $80 \%$ of the babies had suboptimal vitamin $\mathrm{D}$, but were clinically normal ${ }^{14}$. Jain et al found evidence of radiological rickets in only one third of infants with vitamin $\mathrm{D}<10 \mathrm{ng} / \mathrm{ml}$ at around three month of age, though growth retardation or clinical rickets was absent $^{12}$. Gordon et al in their study found that out of 40 babies with vitamin D deficiency only one $(2.5 \%)$ had visible genu varum deformity and only three (7.5\%) exhibited rachitic changes on $\mathrm{X}-\mathrm{ray}^{16}$. These results are in accordance with our study. This suggests that vitamin D deficiency remains subclinical in the majority of patients and even radiological changes are rare.

In the present study seven babies were born with a weight less than $2.5 \mathrm{~kg}$. The average vitamin D level in them was $9.79 \pm 5.21$. Out of this seven low birth weight babies 6 had vitamin D levels below 15ng/ml. In the remaining 23 babies with normal birth weight $91.3 \%$ had vitamin D levels $<15 \mathrm{ng} / \mathrm{ml}$. The average score in this group was $8.58 \pm 4.78$. The difference in the two group was statistically insignificant (t-test, $\mathrm{P}$ $=0.568$ ). This result is in concordance to that obtained by Agrawal et al ${ }^{13}$.

\section{Conclusions}

- Vitamin D deficiency is highly prevalent in exclusively breastfed healthy infants.

- Biochemical rickets is more common than clinical.

- The vast majority of these babies do not have clinical or radiological evidence of rickets as it may take more time to manifest.

- The birth weight has no relation with vitamin D status.

\section{Suggestion}

We propose that exclusively breast fed babies should be supplemented with vitamin $\mathrm{D}$ on a regular basis.

\section{Limitations of study}

- The sample size was small.

- Because of financial constraints and nonavailability of test, parathyroid hormone levels were not done. 
- We could not correlate the gestational age and vitamin D status as we could not recruit preterm babies who were all on vitamin supplementation.

Further studies recruiting large numbers of babies with different gestational ages and birth weights with different exclusion criteria and parathyroid hormone levels should be carried out so that a strong case can be made for vitamin $\mathrm{D}$ supplementation.

\section{Acknowledgment}

This study was sponsored by ICMR (Indian Council of Medical Research) as a part of STS (Short Term Studentship) project.

\section{References}

1. Gulati A, Paul V K. Micronutrients in Health and Disease. In: Ghai OP, Paul VK, Bagga A, editors. Essential Pediatrics $7^{\text {th }}$ ed. New Delhi: CBS Publishers and Distributors Pvt. Ltd; 2009. p 80-81.

2. Misra et al. Vitamin D deficiency in children and its management: review of current knowledge and recommendations. Pediatrics 2008; 122: 398-417.

http://dx.doi.org/10.1542/peds.2007-1894

3. Wielders JP, Muskiet FA, van de Wiel A. Shedding new light on vitamin D- reassessment of an essential prohormone. Ned Tijdschr Geneeskd 2010; 154: A1810

4. Holick MF. Vitamin D deficiency. New England Journal of Medicine 2007; 357:266-81. http://dx.doi.org/10.1056/NEJMra070553

5. Rathi N, Rathi A. Vitamin D and Child Health in the $21^{\text {st }}$ century. Indian Pediatrics 2011; 48:61925.

http://dx.doi.org/10.1007/s13312-011-0107-9

6. Greer FR. 25-Hydroxyvitamin D: functional outcomes in infants and young children. American Journal of Clinical Nutrition 2008; 88(suppl.):529S-33S

7. WHO Monograph, Nutrition in Preventive Medicine. 1976; Sr. No. 62:567.

8. WHO. International classification of diseases. Tenth revision. Vol 2.
9. World Health Organization. WHO Global Data Bank on Breastfeeding. Updated 2003.

10. WHO. Child Growth Standards, Length/ height for age, weight for age, weight for length, weight for height and body mass index for age. Methods and development. 2006.

11. Custer JW, Rachel E, editors. Harriet Lane Handbook. $18^{\text {th }}$ ed. Philadelphia: Mosby; 2008. p.678t.

12. Jain V, Gupta N, Kalavani M, Jain A, Sinha A, Agarwal R. Vitamin D deficiency in healthy breastfed term infants at 3 months and their mothers in India: Seasonal variation and determinants. Indian Journal of Medical Research 2011; 133(3): 267-73.

13. Agarwal N, Faridi MM, Aggarwal A, Singh O. Vitamin D Status of term exclusively breastfed infants and their mothers from India. Acta Paediatrica 2010; 99(11):1671-4. http://dx.doi.org/10.1111/j.16512227.2010.01912.x

14. Bhalala U, Desai M, Parekh P, Mokal R, Chheda B. Subclinical hypovitaminosis D among exclusively breastfed young infants. Indian Pediatrics 2007; 44(12):897-901.

15. Seth A, Marwaha RK, Singla B, Aneja S, Mehrotra P, Sastry A, Khurana ML, Mani K, Sharma B, Tandon N. Vitamin D nutritional status of exclusively breast fed infants and their mothers. Journal of Pediatric Endocrinology \& Metabolism 2009; 22(3):241-6. http://dx.doi.org/10.1515/JPEM.2009.22.3.241

16. Gordon CM, Feldman HA, Sinclair L, Williams AL, Kleinman PK, Perez-Rossello J, et al. Prevalence of vitamin D deficiency among healthy infants and toddlers. Archives of Pediatrics \& Adolescent Medicine 2008; 162: 505-12.

http://dx.doi.org/10.1001/archpedi.162.6.505

17. Gessner BD, Plotnik J, Muth PT. 25-hydroxdy vitamin $\mathrm{D}$ levels among healthy children in Alaska. Journal of Pediatrics 2003; 143: 434-7. http://dx.doi.org/10.1067/S0022-3476(03)00410-4

18. Ziegler EE, Hollis BW, Nelson SE, Jeter MJ. Vitamin D Deficiency in Breastfed Infants in Iowa. Pediatrics 2006; 118:603-10. http://dx.doi.org/10.1542/peds.2006-0108 